\title{
THE PROTECTION OF THE PREEMPTIVE RIGHTS OF SEPARATE AND PLEDGE CREDITORS IN THE CASE OF SALES OF ENCUMBERED PROPERTY BY A DIRECT AGREEMENT
}

\begin{abstract}
The article reviews the regulations of Republic of Serbia, domestic legal practice, as well as the opinions of jurisprudence on the exercise and protection of the preemptive rights of separate and pledge creditors in a bankruptcy proceedings. There has been clarified the legal nature of the preemptive right on the subject of the secured right or lien. There were also provided the details related to the significance of the right of a creditor to set off its secured claim with the purchase price, in the case of a creditor being the best bidder (credit bidding). The article aims to present the manner of exercise of preemptive rights in the case of the method of sales of encumbered property/assets by a direct agreement, as well as the legal instruments the secured creditors may use in the case of its violation. There have been analysed the rules of procedure per lawsuit for annulment of a sale due to the violation of the preemptive rights. The deadline for a lawsuit, the content of the lawsuit which protects the preemptive right as well as the damage compensation right were especially considered.
\end{abstract}

Keywords: bankruptcy, preemptive right, separate creditor, sales, direct agreement.

\footnotetext{
* LLD, Associate Professor, The University of Novi Sad, The Faculty of Technical Sciences, Serbia, e-mail: marijana.mijatovic@uns.ac.rs

** LLD, A full Professor, The Faculty of Law for Commerce and Judiciary in Novi Sad, The University of Business Academy in Novi Sad, Serbia, e-mail: kozarv@pravni-fakultet.info
} 


\section{Introduction}

Initiation of bankruptcy proceedings over the owner of property under mortgage or movables under pledge has a significant impact on a position of secured creditors, regardless of the fact it will not lead to the cessation of real and legal securities, since, as a rule, it disables execution of the procedure of individual enforcement and settlement outside bankruptcy proceedings (Kozar \& Aleksić, 2018, p. 920). Legal prohibition of individual enforcement and settlement occurring as the process and legal consequence of initiation of bankruptcy proceedings shall refer to exercise of rights of separate and pledge creditors. This prohibition is named moratorium in jurisprudence (Obućina, 2017 , p. 36) and court practice ${ }^{1}$. Bankruptcy framework in the Republic of Serbia limits their rights on one hand, and provides extensive guarantees on the other, by prescribing several specific institutes that additionally protect the rights of secured creditors in the procedures of bankruptcy debtor asset sales, which is the topic of this paper. Additional protection of rights is necessary especially nowadays, when the surge of new global recession results in hindered business conduct and collection of claims (Dukić Mijatović, 2013, p. 1).

Law on Bankruptcy-LB, (2009) differs separate and pledge creditors as two categories of secured creditors. The criteria for differentiation are whether the creditor has or does not have claims that are secured by mortgage or pledge over the assets of the bankruptcy debtor, that is, whether the bankruptcy debtor is simultaneously the debtor of the secured claim (debtor from the original transaction) or it is a third party (Dukić Mijatović \& Mijatović, 2011). This right arises from the nature of stated real rights that includes securing specific claims of separate creditors (Čolović \& Milijević, 2020, p. 128). "One should keep in mind that the separate creditor shall be entitled to priority in collection only from certain assets of the bankruptcy debtor, over which there is a secured right of right to settle. Such creditor shall not be entitled a general secured right over the entire assets of the debtor and all of its income, which would aggravate the position of the debtor" (Lazarević, 1956, p. 81). On the other hand, the pledge creditor has real legal security over the assets of the bankruptcy debtor but has no monetary claims towards the bankruptcy debtor that is secured by such secured right (Carić, Vitez, Dukić Mijatović \&

\footnotetext{
${ }^{1}$ Odgovori utvrđeni na sednicama Odeljenja za privredne sporove Privrednog apelacionog suda od 8. i 9.11.2018. godine [Responses Determined at Meetings of Commercial Disputes Department of the Commercial Court of Appeals from 8 and 9 November 2018]. Bilten sudske prakse privrednih sudova [Bulletin of case law of commercial courts], 2/2019, pp. 108-109. Downloaded 2020, June 27 from https://pa.sud.rs/tekst/394/bilteni-sudske-prakse.php
} 
Veselinović, 2016, p. 106). In legal theory, such persons are named "pledge creditors with claims towards third persons" (Radović, 2014, p. 249).

\section{Termination of Previously Acquired Preemptive Rights as a Legal Consequence of Initiation of Bankruptcy Proceedings}

The bankruptcy proceedings, as a process, starts with a petition of the creditor, debtor or liquidator, as authorized petitioners (Law on BankruptcyLB, 2009, Article 55, paragraph 1), while the adoption of the positive decision on such petition, in case the court determines one of the legal bankruptcy reasons, is named initiating bankruptcy proceedings (Kozar, Počuča, \& Stanković, 2013, pp. 87-88).

One of the consequences of initiating bankruptcy proceedings, for the bankruptcy debtor, is termination previously acquired preemptive rights (Šarkić, Radulović \& Počuča, 2019, p. 380). Initiating bankruptcy proceedings terminates contracted preemptive right (Article 527 of the Law of Contracts and Torts - LCT, 1978 (1978), as well as legal preemptive right, for example, preemptive right of the co-owner of property or owner of the neighboring agricultural land (Law on Bankruptcy-LB, 2009, Article 75). At the same time, legal preemptive right is established for the benefit of secured creditor, and persons related to them, on the subject of secured right or lien, in case of method of sales through direct agreement (Law on Bankruptcy-LB, 2009, Article 136g).

"Preemptive right may be defined as the right whose holder is authorized, in case of sales of items to which the preemptive right refers to, acquire such items prior to anyone else, through purchase in case conditions of sale are met that are determined by the owner of the item (seller)" (Cvetić, 2014, pp. 147-148).

Through termination of previously acquired preemptive rights collision with the legal preemptive right of secured creditors, over the subject of secured right or lien is avoided, that would occur had the stated consequence of bankruptcy proceedings initiation not been prescribed. This is the consequence of the effect of preemptive right as an absolute right, that has an erga omnes effect and, as a rule, is mutually exclusive, thus, the same item may not be subjected to two absolute rights of the same type and order at the same time, for the benefit of different title holders. However, should bankruptcy proceedings be terminated due to the adoption of the reorganization plan, and the assets that were subjected to preemptive right is not sold, the preemptive right shall be reestablished (Šarkić, Radulović \& Počuča, 2019, p. 380). 


\section{Legal Preemptive Right of Secured Creditor on the Subject of Secured Right or Lien}

Law on Amendments of the Law on Bankruptcy (2017) introduced Article $136 \mathrm{~d}$ into the original wording of the law, establishing a legal preemptive right for the benefit of the separate, that is, pledge creditor, as well as persons related, on the subject of secured right or lien, in case of method of sales by direct agreement. Hence, in addition to the transaction (for example, contract or last will and testament), the source of preemptive right may be the law (Perović, 1986, p. 573), where the legal preemptive right is applied erga omnes. On the other hand, the contractual preemptive right is applied inter partes thus, only related to the contracting parties (for example, seller and buyer from the contract on sales with preemptive right) and can be applied related to third parties only in case of negligence in particular case (Perović, 1986, p. 573).

When assets that are subject to secured right or lien are sold through direct agreement, the secured creditor may, within five days from the reception of the notice of the bankruptcy administrator on proposed sale, that must include all the terms of the sale that is proposed, including the price and payment method (Law on Bankruptcy-LB, 2009, Article 133 paragraph 6), notify the court and the bankruptcy administrator that it accepts to purchase the subject of sales under conditions from the notice (or more favorable conditions for the bankruptcy debtor) (preemptive right). This additionally protects its position in situations where there are no public announcements of the sales process, when the method of sales is not public bidding or public collection of bids, without damaging the bankruptcy estate, since such creditor, provided that it wishes to use this right, shall be obligated to offer the same terms as offered by the best bidder, at minimum.

The establishment of preemptive right for the separate creditor in case of sales through direct agreement, enables the separate creditor, in case that he is of the opinion that adequate price has not been received, to purchase the subject of sales under the same (or more favorable for bankruptcy debtor) terms from the notice of the bankruptcy administrator on the proposed sales, where the secured claim may be settled against the amount of the purchase price (credit bidding) (Kozar, 2019). In case the right to credit bidding is not exercised, the secured creditor shall, simultaneously with the statement on purchase, be obligated to pay the price agreed with the third party, or deposit it with the court, in line with the application of rules on the price payment deadline (Law of Contracts and Torts - LCT, 1978, Article 528 paragraph 2 and Article 533 paragraph 4), since the rules on preemptive rights shall be 
applied accordingly to the legal preemptive right (Dukić Mijatović \& Kozar, 2019, p. 498).

Preemptive right may be exercised by the separate, or pledge creditors through related persons with the submission of evidence on such related relationship. This right has been primarily established due to requirements of banks as the most significant secured creditors to follow regulatory limitations of investments into fixed assets and investment real estate (Article 34 paragraph 2 of the Law on Banks (2005). This option is valid for other legal entities as well, that are not banks that act in the capacity of secured creditors.

\section{Annulment of a Sale as Sanction for Preemptive Right Violation}

Law on Bankruptcy-LB, 2009, does not prescribe sanctions, that is, legal consequences for the violation of preemptive rights of secured creditors (Kozar, 2019). Hence, it can be concluded that general rules from contract law shall be applied (Law of Contracts and Torts - LCT, 1978, Articles 527-532) that regulate preemptive rights: "1) Preemptive right may be regulated by law for certain persons. (2) Duration of the legal preemptive right shall not be limited. (3) Persons holding preemptive rights by law must be notified in writing on intended sale and its terms, otherwise they shall be entitled to request annulment of sales. (4) Rules on sales with preemptive rights shall be applied accordingly to the legal preemptive right" (Law of Contracts and Torts - LCT, 1978, Article 533).

It can be concluded that secured creditor with legal preemptive right over the subject of secured right or lien shall be entitled to request annulment of sales through direct agreement if not properly notified on the intended sales and its terms. At the same time, secured creditor must request the cessation of the item under the same terms, by way of a cumulative claim (Article 197 paragraph 1 of the Law on Civil Procedure (2011), with the request for sales annulment. Otherwise, in case the plaintiff (secured creditor) does not request the cession under the same terms, then there is no legal interest for a suit for sales annulment which is a process obstruction and a reason for dismissal (Poznić, 1987, p. 194).

Notice on intention, sales plan, method of cashing in, method of sales and sales deadlines shall be delivered 15 days prior to the execution of sales by direct agreement at the latest (Law on Bankruptcy-LB, 2009, Article 133 paragraphs 1 and 2).

Separate, or pledge creditor may file a suit for the annulment of sales contract by direct agreement in a subjective-objective period prescribed by 
law for the annulment of the voidable contract, where the shorter subjective six-month period shall be calculated from the moment of plaintiff's learning about the transfer of ownership, that is, precise contract terms, while the longer objective five-year period shall be calculated from the transfer of title to a third party (Law of Contracts and Torts - LCT, 1978, Article 532). Shorter subjective deadline must be within the longer objective deadline. "Exercise of authority arising from preemptive right is related to strict legal, preclusive deadlines, whose expiry leads to the loss of preemptive right" (Cvetić, 2014, p. 148). Therefore, regardless of the fact the duration of the legal preemptive right is not limited by law (Law of Contracts and Torts - LCT, 1978, Article 533, paragraph 2), preclusive, subjective-objective deadline shall be applied to the sales annulment claim, as prescribed for the contracted preemptive right (Law of Contracts and Torts - LCT, 1978, Articles 532 and 533, paragraph 4).

The court practice from real estate sales disputes took position on the preclusive legal nature of the subjective deadline for the exercise of preemptive right protection: "With the expiration of the subjective deadline starting from the day of receiving knowledge about the conclusion of the real estate sales agreement, the owner of the neighboring plot shall lose the right and possibility to exercise the protection of preemptive right" (The verdict of the Supreme Court of Cassation, Rev. 1788/2017 from 13 September 2018) ${ }^{2}$.

\section{Submission to the Court of the Proposed Purchase Price, the Good Faith of the Purchaser, and Damage Compensation}

"Depositing cash in the amount of market value of the real estate simultaneously with the suit is the basis for probable cause of the claim of the holder of preemptive right for the annulment of the real estate sales agreement and the request for selling the property to such holder under the same terms" (Legal opinion of the Civil Department of the Court of Appeals in Novi Sad from 26 May $2014)^{3}$. Due to the violation of priority in the acquisition of rights that is the essence of the preemptive right, in this way, priority purchase right is activated,

\footnotetext{
${ }^{2}$ Presuda Vrhovnog kasacionog suda, Rev 1788/2017 od 13.09.2018 [The verdict of the Supreme Court of Cassation, Rev. 1788/2017 from 13 September 2018]. Elektronski bilten Osnovnog suda u Novom Sadu [Electronic bulletin of the Basic Court in Novi Sad]. Downloaded 2020, June 29 from http://www.propisionline.com/Practice/Decision/58029

3 Pravno shvatanje usvojeno na sednici Građanskog odeljenja Apelacionog suda u Novom Sadu, od 26.05.2014. godine [Legal opinion of the Civil Department of the Court of Appeals in Novi Sad from 26 May 2014], Bilten Apelacionog suda u Novom Sadu [Bulletin of the Court of Appeals in Novi Sad] 7/2016. Downloaded 2020, January 29 from http://www.propisionline.com/Practice/ Decision $/ 48388$
} 
which is also included in this right. The priority purchase right occurs only if preemptive right has been violated by concluding a contract with a third person (Cvetić, 2014, p. 148). "Preemptive right occurs where there is still no contract, and the priority purchase right occurs only after the conclusion of the valid sales agreement between the owner and the third party" (Orlić, 1978, p. 1114).

However, since the secured creditor shall be entitled to settle its secured claim with the purchase price, in case such creditor is the best bidder (credit bidding), it can be concluded that such creditor shall not have the obligation of simultaneous depositing the amount of the market value of the real estate with the court, in case such creditor intends to exercise its preemptive right in cumulation with the right to settle secured claims with the purchase price, in case such claim exceeds the amount of proposed purchase price. In such case separate or pledge creditor should deposit only the amount of costs of sales and other mandatory costs (property appraisal, advertising, legal obligations, etc.) that include the fee for the bankruptcy administrator (Law on BankruptcyLB, 2009, Article 136b). However, in case the secured claim is lower than the amount of the purchase price, that is, its portion providing the right for priority settlement, such creditor shall be obligated to deposit the amount of costs of sales and other mandatory costs, increased for the difference between the secured claim and full amount of the proposed purchase price.

Legal preemptive right shall be applied erga omnes, while the contracted preemptive right shall be applied inter pares, that is, it may be exercised towards a third party only in case of negligence in particular case (Perović, 1986, p. 576). "Right of priority purchase can always be exercised in case of violation of the legal preemptive right, and in case of violation of the contractual preemptive right only if the person to which the asset was sold was negligent, that is, if such person knew or should have known that preemptive right has been violated" (Cvetić, 2014, pp. 147-148). Therefore, one could accept a position that negligence of the third party (buyer) is not a precondition for the adoption of the claim of the separate, that is, pledge creditor, as the holder of the legal preemptive right for the annulment of sales and cessation of asset under the same terms. In this case the right to damage compensation towards the bankruptcy administrator and/or bankruptcy debtor would belong to a third party and it would be treated as an obligation of the bankruptcy estate (Kozar, 2018, p. 79), caused by actions of the bankruptcy administrator, by cashing in the bankruptcy estate.

Legislator explicitly prescribes that the bankruptcy administrator shall be liable with its personal property for any damages caused, through the performance of duties of the bankruptcy administrator, to participants of the bankruptcy 
proceedings intentionally or with gross neglect (Law on Bankruptcy-LB, 2009, Article 31). Since the bankruptcy administrator is a natural person, with unique property, such administrator would be liable for damages with personal property, even if such legal provision did not exist (Kozar, 2012). However, the "liability of the administrator is limited to qualified forms of guilt" (Karanikić Mirić, 2019 , p. 647). According to the interpretation prevailing in jurisprudence, the law prescribes a severe form of guilt as the basis for the liability of the bankruptcy administrator, meaning that the damage occurring due to ordinary negligence of the bankruptcy administrator (culpa levis) may not lead to determination of its liability (Slijepčević \& Spasić, 2006, p. 70). According to one opinion, the damage caused to participants in the proceedings intentionally or with gross neglect shall be subject of joint liability of the bankruptcy administrator and the state, and in case damage was caused by ordinary neglect, then only the liability of the state shall exist (Kozar \& Počuča, p. 135). There are contrary opinions in jurisprudence: "In Serbian law there is no liability for the bankruptcy administrator as per rules on out-of-contract liability for other parties. The state shall not be liable for damages caused by the bankruptcy administrator while performing his/her duties, regardless of whether such damage was caused to the participant in bankruptcy proceedings or third party. The bankruptcy administrator is a body of the bankruptcy proceedings, but not a body of the state. Bankruptcy administrator is not a state official either" (Karanikić Mirić, 2019, p. 638).

\section{Conclusion}

One of the consequences of opening bankruptcy proceedings is the establishment of the legal preemptive right for the benefit of secured creditors and persons related to them, over the subject of secured right or lien, in case of sales method by direct agreement. Credit bidding provides the right to the secured creditor to, in case of sales of assets under burden, use the amount of its claim instead of money to pay the price. In case the right to settle the claim with the amount of purchase price is not exercised, the secured creditor shall, simultaneously with the statement confirming the purchase, pay the price agreed with the third party, or deposit such amount with the court.

Preemptive right may be exercised through related parties, which enables the banks, as the largest creditors, to purchase certain assets of the bankruptcy debtor, following regulatory limitations of investments into fixed assets and investment real estate.

In case the holder of the legal preemptive right is not notified in writing on the intended sales and its terms, such holder shall be entitled to request 
annulment of sales. With such request, the secured creditor must seek cessation of the item under the same terms by way of cumulative claim.

Preclusive objective six-month deadline for suit shall be counted from the moment of plaintiff learning about the transfer of ownership, that is, precise contract terms, where the suit cannot be filed after the expiration of the objective five-year deadline counting from the transfer of ownership to a third party.

Negligence of the purchaser shall not be a precondition for adoption of the claim for annulment of sales due to violation of legal preemptive right, and the cessation of the item to the secured creditor, under the same terms. In this case, the purchaser shall be entitled to damage compensation by the bankruptcy administrator. Liability of the bankruptcy administrator shall be limited to intention and gross negligence, as qualified forms of guilt, meaning administrator shall not be liable for damages caused by ordinary neglect to the purchaser of assets under burden or other participant in proceedings.

\section{Dukić Mijatović Marijana}

Doktor pravnih nauka, Vanredni profesor, Fakultet tehničkih nauka, Univerzitet u Novom Sadu, Srbija

\section{Kozar Vladimir}

Doktor pravnih nauka, Redovni profesor, Pravni fakultet za privredu i pravosuđe u Novom Sadu, Univerzitet Privredna akademija u Novom Sadu, Srbija

\section{ZAŠTITA PRAVA PREČE KUPOVINE RAZLUČNIH I ZALOŽNIH POVERILACA U SLUČAJU PRODAJE OPTEREĆENE IMOVINE NEPOSREDNOM POGODBOM}

REZIME: U radu su analizirani propisi Republike Srbije, stavovi domaće sudske prakse, kao i mišljenja pravne nauke o ostvarivanju i zaštiti prava preče kupovine razlučnih i založnih poverilaca u stečajnom postupku. Objašnjena je pravna priroda zakonskog prava preče kupovine na predmetu razlučnog, odnosno založnog prava. Detaljno je objašnjen značaj prava poverioca da prebije svoje obezbeđeno potraživanje sa kupoprodajnom 
cenom, za slučaj da je on najbolji ponudilac (credit bidding). Cilj rada je da se prikaže način ostvarivanja prava preče kupovine u slučaju metoda prodaje opterećene imovine neposrednom pogodbom, kao i pravna sredstva koja obezbeđeni poverioci mogu da koristite u slučaju njegove povrede. Analizirana su pravila postupka po tužbi za poništenje prodaje zbog povrede prava preče kupovine. Posebno je razmotren rok za tužbu, sadržina tužbenog zahteva kojim se štiti pravo preče kupovine, kao i pravo na naknadu štete.

Ključne reči: stečaj, pravo preče kupovine, razlučni poverilac, prodaja, neposredna pogodba.

\section{References}

1. Carić, S., Vitez, M., Dukić Mijatović, M., \& Veselinović. J. (2016). Privredno pravo [Commercial Law]. Novi Sad: Univerzitet Privredna akademija, Fakultet za ekonomiju i inženjerski menadžment

2. Cvetić, R. (2014). Pravo preče kupovine u izvršnom postupku u Republici Srbiji [Preemptive Right in Enforcement Proceedings in the Republic of Serbia]. Zbornik radova Pravnog fakulteta u Novom Sadu, 48(4), pp. 147-160

3. Čolović, V., \& Milijević, N. (2020). Stečaj teorija-praksa [Bankruptcy Theory-Practice]. Banja Luka: Udruženje pravnika Republike Srpske

4. Dukić Mijatović, M., \& Kozar, V. (2019). Postulati korporativnog stečaja u Republici Srbiji [Postulates of Corporate Bankruptcy in the Republic of Serbia]. Novi Sad: Pravni fakultet za privredu i pravosuđe

5. Dukić Mijatović, M., \& Mijatović, M. (2011). Pravni položaj razlučnih poverilaca u stečaju [Legal Status of Separate Creditors in Bankruptcy]. Pravni život, 60 (11), pp. 205-221

6. Dukić Mijatović, M. (2013). Pravni položaj poverilaca obezbeđenih potraživanja u finansijskom restruktuiranju i stečaju [Legal Status of Creditors of Secured Claims in Financial Restructuring and Bankruptcy]. Pravo, teorija i praksa, 30 (1-3), pp. 1-13

7. Karanikić Mirić, M. (2019). Vanugovorna odgovornost stečajnog upravnika [Extra-contractual Liability of Insolvency Administrators]. Pravo $i$ privreda, 57(4-6), pp. 627-648

8. Kozar, V. (2019). Prebijanje potraživanja i credit bidding u stečajnom postupku [Settlement of Claims and Credit Bidding in Bankruptcy Proceedings]. In: Kulić, M., (ed.), Privrednopravni okvir i ekonomski 
razvoj država Jugoistočne Evrope. [Legal framework and economic development of the countries of Southeast Europe] (pp. 69-90). Novi Sad: Pravni fakultet za privredu i pravosuđe

9. Kozar, V., \& Aleksić, N. (2018). Zabrana izvršenja i namirenja kao procesnopravna posledica otvaranja stečajnog postupka [Prohibition of Enforcement and Settlement as Process and Legal Consequence of Initiation of Bankruptcy Proceedings]. In: Mićović M. (ed.), Savremeni pravni promet $i$ usluge[Modern legal transactions and services] (pp. 920-942). Kragujevac: Pravni fakultet Univerziteta u Kragujevcu

10. Kozar, V. (2018). Pravo preče kupovine obezbeđenih poverilaca u stečajnom postupku [Preemptive Right of Secured Creditors in Bankruptcy Proceedings]. Pravni informator,(1), pp. 34-38

11. Kozar, V., Počuča, M., \& Stanković, I. (2013). Opšti stečajni postupak [General Bankruptcy Proceedings]. Beograd: Poslovni biro

12. Kozar, V. (2012). Građansko-pravni osnovi odgovornosti stečajnog upravnika i države u stečajnom postupku [Civil-Legal Basis of Bankruptcy Administrator and State Liability in Bankruptcy Proceedings]. Pravo, teorija i praksa, 29 (1-3), pp. 44-59

13. Kozar, V., \& Počuča, M. (2011). Šteta u stečajnom postupku [Damages in Bankruptcy Proceedings]. In: Petrović, Z. (ed.), Osiguranje, naknada štete i novi građanski sudski postupci [Insurance, Compensation for Damages and New Civil Court Procedures] (pp. 135-149). Beograd: Intermex

14. Lazarević, A. (1956). Osnovi izvršnog postupka sa stečajnim postupkom i prinudnom likvidacijom preduzeća [Basis of Enforcement Proceedings with Bankruptcy Proceedings and Compulsory Company Liquidation]. Skoplje: Univerzitet u Skoplju

15. Orlić, M. (1978). Pravo preče kupovine [Preemptive Right]. In: Ristić, S., (ed.), Enciklopedija imovinskog prava i prava udruženog rada, tom 2 [Encyclopedia of Property Law and Associated Labor Law, Volume 2] (p. 1114) Beograd: Službeni list SFRJ

16. Obućina, J. (2017). Odnos prethodnog stečajnog postupka i postupka sprovođenja izvršenja radi namirenja novčanog potraživanja na nepokretnostima [Relationship Between Prior Bankruptcy Proceedings and Enforcement Proceedings for Settlement of Monetary]. Pravo i privreda, 55 (1-3), pp. 36-49

17. Perović, S. (1986). Obligaciono pravo [Contract Law]. Beograd: NIU Službeni list SFRJ 
18. Poznić, B. (1987). Građansko procesno pravo [Civil Procedural Law]. Beograd: Savremena administracija

19. Slijepčević, D., \& Spasić, S. (2006). Komentar Zakona o stečajnom postupku [Comment on the Law on Bankruptcy Proceedings]. Beograd: Ces Mecon

20. Radović, M. (2014). Položaj založnih (,hipotekarnih“) poverilaca u stečajnom postupku [Position of Pledge (,Mortgage“) Creditors in Bankruptcy Proceedings]. Pravo i privreda, 52 (4-6), pp. 245-250

21. Šarkić, N., Radulović, D., \& Počuča, M. (2019). Posebni građanski postupci [Special Civil Procedures]. Beograd: Pravni fakultet Univerziteta Union u Beogradu; JP Službeni glasnik

22. Zakon o stečaju [Law on Bankruptcy - LB]. Službeni glasnik RS, no. 104/09, 99/11, 71/12 (Odluka Ustavnog suda), 83/14, 113/17, 44/18, $95 / 18$

23. Zakon o obligacionim odnosima [Law on Contracts and Torts - LCT]. Službeni list SFRJ, no. 29/78, 39/85, 45/89, 57/89, Službeni list SRJ, no. 31/93, (Uredba - za vreme ratnog stanja: 22/99, 23/99, 35/99, 44/99), Službeni glasnik RS, no. 18/20

24. Zakon o izmenama i dopunama Zakona o stečaju, [Law on Amendments of the Law on Bankruptcy]. Službeni glasnik RS, no. 113/17

25. Zakon o bankama [Law on Banks]. Službeni glasnik RS, no. 107/05, $91 / 10,14 / 15$

26. Zakon o parničnom postupku [Law on Civil Procedure]. Službeni glasnik $R S$, no. 72/11, 49/13 (Odluka Ustavnog suda), 74/13 (Odluka Ustavnog suda), 55/14, $87 / 18,18 / 20$ 